\title{
Book review: René Girard and Secular Modernity: Christ, Culture, and Crisis, written by Scott Cowdell
}

\author{
Colby Dickinson \\ Loyola University Chicago, cdickinson1@luc.edu
}

Follow this and additional works at: https://ecommons.luc.edu/theology_facpubs

\section{Recommended Citation}

Dickinson, Colby. Book review: René Girard and Secular Modernity: Christ, Culture, and Crisis, written by Scott Cowdell. International Journal of Public Theology, 8, 4: 489-493, 2014. Retrieved from Loyola eCommons, Theology: Faculty Publications and Other Works, http://dx.doi.org/10.1163/

15697320-12341369

This Book Review is brought to you for free and open access by the Faculty Publications and Other Works by Department at Loyola eCommons. It has been accepted for inclusion in Theology: Faculty Publications and Other Works by an authorized administrator of Loyola eCommons. For more information, please contact ecommons@luc.edu.

\section{(c) (†) $\ominus$}

This work is licensed under a Creative Commons Attribution-Noncommercial-No Derivative Works 3.0 License. (c) Brill, 2014. 
Scott Cowdell, René Girard and Secular Modernity: Christ, Culture, and Crisis, Notre Dame, IN: University of Notre Dame Press, 2013, xi + 259pp., ISBN 978-0-268-02374-4

From the very beginning of this detailed study of the work of René Girard in relation to the prospects of an ongoing secularized modernity, we are introduced to a somewhat bleak, somewhat hopeful vision for the modern world: 'It is a fragile modernity, an incomplete secularization, and a dark future that Girard offers us. Unless we learn the Gospels' lesson and draw back from the brink' (p. 14). In a nutshell, this depiction of the state of modernity, as permeated by violence as it is and continues to be, is what Scott Cowdell presents us with in his René Girard and Secular Modernity: Christ, Culture, and Crisis.

The first few chapters of the book rehearse what Cowdell calls La système Girard: from the most basic mimetic ('imitative') desiring processes (put simply, wanting what the other person wants) - the 'real unconscious', as Girard himself calls it (p. 27) — to the true nature and significance of rivalry and scandal, culminating in the selection and sacrificial exclusion (or death) of a scapegoat in order to regulate the violent impulses of society, Cowdell takes us through a grand journey in mythological and modern literary narratives in the hopes that Girard might offer us a genuine glimmer of hope for the world around us.

Marshalling in a rather large, and at times daunting pantheon of notable modern figures, Hobbes and Rousseau, of course, but also, in a more sustained manner, both Freud and Nietzsche, Cowdell focuses our attention upon a Girardian reading of modernity - in a specific sense, the freedom and autonomy offered by modernity and the processes of secularization that are actually a further entrenching of the perils of mimetic desire. As he describes the location where the western subject resides, 'Here is the hypermimetic Western "individual” whose illusory independence and greatness grow proportionally with their mimetic compulsion and self-engineered adversity in the grip of an insurmountable obstacle' (p. 50). Violence, including self-violence, which is here given its proper due, gives rise to more violence, often finding new and nefarious ways to conceal itself, and as it moves from its mundane expressions (i.e. gossip, video games) to large scale, even global projects of terror.

Putting Girardian theories in dialogue with recent developments in cognitive neuroscience and developmental psychology, as well as highlighting connections between mimetic theory and the aggression and 'ritual' present in certain animal species, Cowdell draws our attention to the way in which Girard's theories are less individualistic than modern psychological theories, more socially-oriented, and thus more nuanced in their account of modern forms of narcissism, or rather 'pseudo narcissism', according to Girard, since it is more a strategy for self-sufficiency, attainable through violent means, than a 'metaphysical' condition per se. As such, everything seemingly reverts to its social-mimetic platform, including his interpretation of the breakdown of the boundary between 'I' and 'you' today, which he characterizes as follows: 'We crave differentiation, and deprived of it we blame the failing institutions that once might have delivered it' (p. 35). Related to these 'failing institutions', then, come a host of social problems which Cowdell seeks to clarify within Girard's work: the ambiguities within Girard's comments on homosexuality, which tend to focus on forms of same-sex relations that develop at the moment when a rivalry between two persons becomes sexualized, a focus upon James Alison's further development of Girardian thought 'in a more explicitly gay-friendly direction' (p. 41), and a rereading of Sadism and Masochism as extreme tendencies found within mimetic processes grown out of control.

Moving away from the rush of mimetic desire and taking up the mundane, ordinary responsibilities of life is the solution to such modern 'madness', he will posit. And so, he takes up a summary and analysis of the scapegoating or sacrificial mechanism that permeates Girard's analysis of culture and which functions culturally as the 'center of signification' for society (p. 61). Cowdell elaborates a good deal on how Girard sees this mechanism as a sort of evolutionary progress, an attempt to deal with what has resulted in the human species regarding our propensity to violence and our need to regulate it. Reaching back to what could be described as humanity's first encounters with violence, he imagines how, when confronted with the violence of the sacrificial victim, 'Its newness, terror, wonder, and incomprehensibility at the level of instinct combine to make this first cultural symbol one of prohibition [...]' (p. 62), one from which, in Girard's estimation, all subsequent taboos and rituals spring.

Since the approach of the book is one that undertakes to narrate Girardian theory in light of the historical evolution of humanity, Cowdell turns to the rise of a 'false sacrality' that comes about through the double process of sacralizing the victim of scapegoating and the reconciliation subsequently experienced by the community through their death. The book is at its strongest, as many Girardian commentaries are, when immersed in the discussion of primitive rituals, ancient tragedies, and foundational persecution texts, for it is here that the clear lines of La système Girard are made bold: mimetic desire, scandal and crisis, the selection of a scapegoat based on their perceived difference, the exclusion or sacrifice of the victim, and the eventual concealment of the real violence which is done to very real victims. These various stages are unfolded with precision by Cowdell, who likewise points out how persecution texts, such as those inciting hatred against Jews or 'witches', are actually narratives that have, for their 
part, failed to actually become sacred—an increasingly modern phenomenon that speaks to the slow influence of the Christian message, and which is inescapably part of the processes of secularization that have taken place as a form of modern progress made against such violence. Such a 'desacralization' occurs, then, when myth is replaced 'by an awareness of persecution' in society (p. 81), something which is noted in certain Hindu and Buddhist traditions, but most fully disclosed by the Hebrew and Christian narratives.

Hence, as we are repeatedly shown, it is in the depiction of counterviolent stories, from Cain and Abel to Joseph and his brothers, from the commandments and Exodus to the prophets, Job and the Psalms, and eventually to Jesus, that the biblical scriptures come alive and present to the world an alternative to pagan legitimations of violence. Cowdell provides a fitting summary of both Girard's explications and Girardian commentators who have sought to connect his insights to other biblical passages, including several creative readings of Jesus, his teachings, his actions against the scapegoating mechanism, and the character of Satan in the Gospels. There are many implications for such reasonings, including the uniqueness of the biblical narrative, the call to renounce mimetic violent aims, and the reformulation (or outright rejection) of many 'traditional' Christian teachings, including various atonement theories: 'But Jesus' death is not God's doing, let alone any sort of price exacted by God. Such misguided Christian (and atheistic) readings of the passion texts are dismissed by Girard as just one more chapter in the history of sacrificial religion' (p. 98).

Jesus brings about through his presence a form of 'countertranscendence' (p. 99) to the world, significantly through his rereading of the violence that is infused in our world, as well as his innocent victimhood. The modern 'death of God' touted through western thought (and theology) is little more than the recognition of the death of those certain archaic and violent gods of sacrificial madness, which the Gospel story in fact helps to bring about, even if the history of Christianity demonstrates that this message is often still waiting to be received within the Church. Jesus' death and resurrection, for Girard, issue in the final revealing of the scapegoat mechanism and condemn it for what it is, 'paganism's way of organizing the world' (p. 103). It is as such that Girard deplores certain 'irreligious' forms of secularism that 'keep paganism alive covertly' (p. 111), and which thereby seek also to condone certain social forms of violence - a point which Cowdell underscores in order to provide a fuller portrait of what actually occurs within a modern landscape.

In the second, and most original, portion of the book, Cowdell turns his gaze toward 'Modern Institutions and Violence' and the rise of radical Islamic terrorism, hoping to illuminate the continued significance of Girard's work for a contemporary audience. Making explicit the connection between Girardian readings of texts and the stakes of modern culture, he contends that 'Modernity [...] is a shift from hierarchy to equality, from differentiation to undifferentiation, from external to internal mediation. It is the social shift to a more level playing field, but it also increases the risk of envy, rivalry, and violence' (p. 117). When you throw the forces of secularization into the mix, what you achieve is an 'increased risk of violence with reduced protection', one in which particular modern institutions are left to bear the brunt of the tasks that religion had once borne. Though this is a frightening prospect for Girard, to be sure, Cowdell hopes to provide some much needed clarity to Girard's program by critically engaging the rise of 'civil religion', late modern capitalism and 'consumer culture', and self-harm as a form of 'ontological sickness' characteristic of self-sacrifice (here including brief analyses of anorexia, abortion and capital punishment), all in order to show how Girard's thesis speaks to these issues, among others, today.

The discussion of secular modernity eventually dovetails into the late apocalyptic visions of Girard concerning the current paths of civil war and escalating violence that our world is set upon. Here, Cowdell provides us with a unification of Girard's post-9/11 comments on how Islam has been coopted as a form of globalized 'political religion' since it is 'a more amenable host nowadays than Christianity because it has not offloaded the false sacred as extensively as has Christianity' (p. 154). Referring then to a stringent critique of 'jihadism' offered by Girard, Cowdell points out how Islam itself differs from such impulses, as well as how 'the chief antipathy of radical Islam is Christianity itself, rather than secular Western society' (p. 153), thus displaying the irreducible uniqueness of the biblical narratives in the face of globalized religious trends, a point that does promote a certain 'clash of civilizations', though one that is, in his eyes, an unavoidable conclusion of Girardian thought, and one very much bent, by its nature, on a peaceful resolution to any such conflict.

This apocalyptic viewpoint, as offered in Girard's more recent book Battling to the End, is formulated as an effort to bring his mimetic theory into historical terms vis-à-vis the work of Carl von Clausewitz, and which concludes with a totalized concept of war that leaves us gasping at how, now, much as in Foucault's analysis elsewhere, 'war exists everywhere' (p. 161). Through a barrage of contemporary political and military examples, Cowdell illustrates, albeit hastily at times, how in preparing for defense, one only escalates the violence, and neglects the larger processes of mimetic desiring that continue to push the world along a path toward its extinction. Cowdell does take Girard slightly to task for seeming to capitulate to the 'necessity' of violence in the promotion of 
a greater peace, something which points Cowdell toward authors such as Walter Wink instead in seeking out nonviolent, practical solutions to the contagion of violence within our world.

In the end, there is little else that remains beyond a call to conversion to a Judeo-Christian outlook on violence, which, in this context, is imperative when considering the violence that infiltrates every aspect of life today, though not in terms that seek to do so only to underwrite a Christian imperialist agenda: 'This is what being Christian entails: coming to share mimetically in Christ's nonrivalrous desire, which uproots self-definitional hatred against the despised other and the violence that follows. The resultant profile is, paradoxically, one of powerlessness, which alone proves able to truly change the world [...]' (p. 171). So, call it 'Christian', or perhaps instead emphasize this 'Christian' element within another religious tradition; either way, one's stance in relation to violence becomes the definitive measure by which all religious faiths are judged-including Christianity. Imitatio Christi can henceforth be read on another level altogether, as it serves as a reminder that Christians are called not to imitate Jesus, but God, and thus introduce us to the renunciation of certain mimetic desires, perhaps even the desire to label ourselves as 'Christians' in the first place - though Cowdell himself does not here suggest this. What he does explore is a general welcome for all into a (Christian) formulation of a 'rootlessness that trumps belonging' (p. 179), and which is sacramental- 'an invitation to mystery' (p. 181) insofar as it cannot be satisfying according to the world's (mimetic) desires. His is, then, a 'modest' Christian proposal for peace, but one that may have no other genuine alternatives before it.

There are many widely speculative elements within Girard's estimations of society's foundations, though they are ones that generally ring true with his profound and insightful readings of mythological and literary narratives, something which lends a great deal of weight to his claims overall. Cowdell's book touches upon a good many subjects, often far more briefly and speculatively than I would have otherwise desired, but my desires were on this point also generated by the successes which the book did register to my mind. I eagerly anticipate his promised next volume on Girardian thought, and I continue to weigh all that I have profited by my reading of this one. 